\title{
Iridium Catalyzed Deoxygenation of Epoxides with Carbon Monoxide
}

\author{
Theo Maulbetsch, Eva Jürgens and Doris Kunz ${ }^{*[a]}$ \\ Institut für Anorganische Chemie, University of Tübingen, Auf der Morgenstelle 18, D-72076 Tübingen, Germany, E-mail: Doris.Kunz@uni- \\ tuebingen.de
}

\begin{abstract}
The use of carbon monoxide as a direct reducing agent for the deoxygenation of a broad range of terminal and internal epoxides to the respective olefins is presented. This reaction is homogeneously catalyzed by a carbonyl pincer-iridium(I) complex in combination with a Lewis acid co-catalyst to achieve a pre-activation of the epoxide substrate as well as the elimination of $\mathrm{CO}_{2}$ from a $\mathrm{y}$-2-iridabutyrolactone intermediate. Especially terminal alkyl epoxides react smoothly and without significant isomerization to the internal olefins under $\mathrm{CO}$ atmosphere in benzene or toluene at $80-120^{\circ} \mathrm{C}$. Detailed investigations reveal a substrate-dependant change in the mechanism for the epoxide $\mathrm{C}-\mathrm{O}$ bond activation between an oxidative addition under retention of the configuration and an $\mathrm{S}_{\mathrm{N}} 2$ reaction that leads to an inversion of the configuration.
\end{abstract}

\section{Introduction}

Apart from the water-gas shift reaction itself as well as reductions using hydrogen produced by this reaction in situ ${ }^{[1]}$, the use of carbon monoxide as a direct deoxygenation agent is very rare in homogenous catalysis and hard to distinguish from the former one depending on the system ${ }^{[1-4]}$. The deoxygenation of epoxides to alkenes is an important reaction in organic chemistry and some noncatalytic as well as catalytic reactions (homogeneous and heterogeneous) are known. One early report on the deoxygenation of epoxides was in 1956 by Wittig and Haag, ${ }^{[5]}$ who used triphenylphosphine as a deoxygenation reagent at $180{ }^{\circ} \mathrm{C}$ to deoxygenate $\alpha, \beta$ epoxy esters that were obtained from the Darzens reaction. They recognized that the temperature can be reduced when adding hydroquinone. Vedejs and Fuchs developed this reaction further by reacting cis or trans epoxides to the betaines with lithium diphenylphosphide and methyl iodide, which subsequently led to formation of the olefin with inversion of the configuration at room temperature. ${ }^{[6,7]}$ Later, rhenium catalyzed variations were developed. ${ }^{[8,9]}$ In all these cases, the stoichiometric amounts of triorganophosphine oxide as a side product is problematic to get recycled back to the phosphine or phosphide. Other stoichiometric or overstoichiometric deoxygenation reagents for epoxides ${ }^{[10,11]}$ are $\mathrm{Co}_{2}(\mathrm{CO})_{8},{ }^{[12]} \mathrm{Fe}(\mathrm{CO})_{5},{ }^{[13]} \mathrm{Sml}_{2},{ }^{[14]} \mathrm{In} / \mathrm{InCl},{ }^{[15]}$ lithium amide bases with silylboranes ${ }^{[16]}$ or diazomalonate ${ }^{[17]}$. The latter two are catalyzed by copper-nanoparticles and copper complexes respectively. Not yet fully understood is the deoxygenation of arene oxides and their oxepine tautomers by $\left[\mathrm{Rh}(\mathrm{CO})_{2} \mathrm{Cl}\right]_{2}$ or $\left[\mathrm{Rh}\left(\mathrm{C}_{2} \mathrm{H}_{4}\right)_{2} \mathrm{Cl}_{2}\right.$ in $\mathrm{CHCl}{ }_{3}$. $\left.{ }^{[8-20}\right]$ Environmentally much more benign are variations in which hydrogen is used as a deoxygenation agent to obtain water as a byproduct. Methylrheniumtrioxide $\left(\operatorname{Re}\left(\mathrm{CH}_{3}\right) \mathrm{O}_{3}\right)$ is a suitable catalyst for this reaction that is carried out at $150{ }^{\circ} \mathrm{C}$. However, the hydrogenation of the product olefins can be an unwanted side reaction. ${ }^{[21]}$ Silver and gold nanoparticles are heterogeneous catalysts in a process that uses hydrogen directly ${ }^{[22]}$ or generates it in situ from water or alcohols. ${ }^{[23]}$ The currently most efficient system uses reactive hydrogen species that are produced in an in situ water gas shift reaction from carbon monoxide by a hydrotalcite-supported gold nanoparticle catalyst. ${ }^{[24,25]}$ However, above $50^{\circ} \mathrm{C}$ the formation of free hydrogen is observed, which increases the CO consumption and requires additional security measures. While aryl oxiranes already react at room temperature, alkyl oxiranes need temperatures of $110^{\circ} \mathrm{C}$ and an organic solvent.

In the following, we will report on the efficient and stereoselective deoxygenation of terminal and internal alkyl oxiranes as well as aryl oxiranes with carbon monoxide as a direct deoxygenation agent catalyzed by the nucleophilic carbonyl pincer-complexes $1^{[26]}$ and $2^{[27]}$. Using CO directly is advantageous as the formation of hydrogen, which can cause further side reactions, is avoided per se. In combination with the Johnson-CoreyChaykovsky reaction of aldehydes with sulfur ylides to epoxides, this sequence equals to the Wittig reaction, but with formation of $\mathrm{CO}_{2}$ instead of triphenylphosphine oxide.

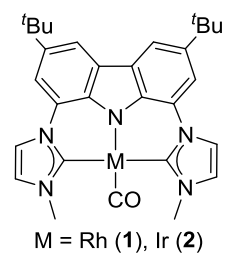

\section{Results and Discussion}

In 2015 we reported on the nucleophilic isomerization of terminal epoxides to methyl ketones using the electron rich carbonyl pincerrhodium catalyst 1 in combination with $\mathrm{LiNTf}_{2}$ as a Lewis acid co-catalyst. ${ }^{[28]}$ As one of the observed side reactions was a CO insertion into the ring-opened intermediate, we envisaged the possibility of a catalytic reaction to obtain $\beta$-lactones, as it is known for $\mathrm{Co}_{2}(\mathrm{CO})_{8} \cdot{ }^{[29,30]}$ However, we were surprised, when we found propylene as the only organic product when reacting propylene oxide, 5 mol\% of 1 and 20 mol\% of $\mathrm{LiNTf}_{2}$ under 15 bar of $\mathrm{CO}$ in $\mathrm{C}_{6} \mathrm{D}_{6}$ at $80{ }^{\circ} \mathrm{C}$ (Scheme 1). The formation of $\mathrm{CO}_{2}$ was recognized in the ${ }^{13} \mathrm{C}$ NMR spectrum.

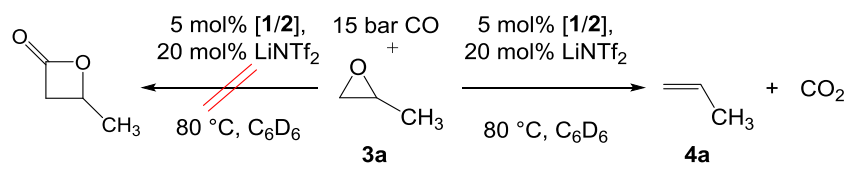

Scheme 1. Deoxygenation of epoxides (right) with $\mathrm{CO}$ catalyzed by the electron rich pincer complexes $\mathbf{1}$ and $\mathbf{2}$. The formation of $\beta$-lactones is not observed. 
This prompted us to investigate this unusual reactivity further. While the rhodium catalyst $\mathbf{1}$ seemed to be unstable at the elevated temperature, we were pleased to find that the analogous iridium complex $\mathbf{2}$ was not only more stable, but also considerably more active (Table 1, entry 5). Other (commercially available) rhodium, iridium, cobalt or iron complexes were much less active under the identical conditions (entries 2-4 and 7-9). With the pincer complex $\left[\operatorname{Ir}\left(\mathrm{bimca}^{\mathrm{C} 5}\right) \mathrm{CO}\right]$, in which the carbene moieties are connected via a 1,5-pentadiyl chain $\left(\right.$ bimca $^{\mathrm{C} 5}$ ), mainly the epoxide isomerization product, methyl butyl ketone, was detected (entry 6).

Table 1. Catalytic deoxygenation of 1,2-epoxyhexane with $\mathrm{CO}^{\mathrm{a}}$

\begin{tabular}{|c|c|c|c|c|}
\hline & $\mathrm{O}_{\mathrm{Bu}} \frac{[\mathrm{Ca}}{\mathrm{O}}$ & $\frac{\mathrm{iNTf}_{2}, \mathrm{CO}}{80^{\circ} \mathrm{C}}$ & $\overline{\mathrm{Bu}}_{\mathrm{Bu}}$ & $+\mathrm{CO}_{2}$ \\
\hline Entry & Catalyst & Time & $\begin{array}{l}\text { Yield } \\
\text { (alkene) } \\
\text { b }\end{array}$ & Side product ${ }^{b}$ \\
\hline 1 & {$\left[\mathrm{Rh}\left(\right.\right.$ bimca $\left.\left.^{\mathrm{Me}}\right) \mathrm{CO}\right](\mathbf{1})$} & $24 \mathrm{~h}$ & $50 \%$ & -- \\
\hline 2 & {$\left[\mathrm{RhCl}\left(\mathrm{PPh}_{3}\right)_{3}\right]$} & $24 \mathrm{~h}$ & $0 \%$ & -- \\
\hline 3 & {$\left[\operatorname{lr}(\mathrm{CO}) \mathrm{Cl}\left(\mathrm{PPh}_{3}\right)_{2}\right]$} & $24 \mathrm{~h}$ & $0 \%$ & -- \\
\hline 4 & {$\left[\operatorname{lr}(\right.$ acac $\left.)(\mathrm{CO})_{2}\right]$} & $\begin{array}{l}24 \mathrm{~h} \\
90 \mathrm{~h}\end{array}$ & $\begin{array}{l}31 \% \\
68 \%\end{array}$ & -- \\
\hline 5 & {$\left[\operatorname{lr}\left(\mathrm{bimca}^{\mathrm{Me}}\right) \mathrm{CO}\right](2)$} & $24 \mathrm{~h}$ & $98 \%$ & $2 \%$ int. olefin \\
\hline 6 & {$\left[\operatorname{lr}\left(\right.\right.$ bimca $\left.\left.^{\mathrm{C} 5}\right)(\mathrm{CO})\right]$} & $24 \mathrm{~h}$ & $8 \%$ & $\begin{array}{l}87 \% \text { methyl butyl } \\
\text { ketone }\end{array}$ \\
\hline 7 & {$\left[\mathrm{Co}(\mathrm{Cp})(\mathrm{CO})_{2}\right]$} & $24 \mathrm{~h}$ & $0 \%$ & -- \\
\hline 8 & {$\left[\mathrm{Co}_{2}(\mathrm{CO})_{8}\right]$} & $24 \mathrm{~h}$ & $0 \%$ & -- \\
\hline 9 & {$\left[\mathrm{Fe}(\mathrm{CO})_{5}\right]$} & $24 \mathrm{~h}$ & $0 \%$ & -- \\
\hline
\end{tabular}

[a] reaction carried out in a pressure NMR tube (Wilmad) at 10 bar $\mathrm{CO}$ and $0.2 \mathrm{M}$ epoxide concentration. [b] from ${ }^{1} \mathrm{H}$ NMR calibrated to $1,3,5$-trimethoxybenzene as internal standard.

Therefore, we optimized the reaction conditions for catalyst 2 (Table 2). Without catalyst or without co-catalyst, the reaction did not

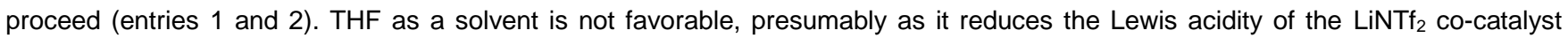
(entry 7). Afterwards we probed the pressure dependence of carbon monoxide. The reaction rate is roughly pressure-independent (entries 8-10). However, at low pressure, the amount of $\mathrm{CO}$ (1.2 equivalents) comes close to the required stoichiometric amounts in our setup (Wilmad Pressure NMR tubes) and thus the insufficient amount of $\mathrm{CO}$ dissolved in benzene explains the lower yields. At 15 bar the yield seems to decrease slightly (entry 10). Therefore, we chose 10 bar as an optimal pressure in all further experiments. To shorten the reaction time we also increased the temperature and found full conversion at $100{ }^{\circ} \mathrm{C}$ after $8 \mathrm{~h}$ and at $120{ }^{\circ} \mathrm{C}$ after $2 \mathrm{~h}$ (entry 11-12). Even at room temperature some product formed, but at a very slow reaction rate (entry 13). With 1-hexene oxide, we recognized a slow isomerization of 1-hexene to internal hexenes. The degree of isomerization increases, when the reaction mixture is kept at the reaction conditions after full conversion of the epoxide. This isomerization also requires the presence of the Lewis acid as a co-catalyst as it was confirmed by independent measurements (Supporting Information).

Table 2. Catalytic deoxygenation of 1,2-epoxyhexane with $\mathrm{CO}^{\mathrm{a}}$

\begin{tabular}{|c|c|c|c|c|c|c|c|c|c|}
\hline \multirow[b]{2}{*}{ Entry } & \multirow[b]{2}{*}{$\begin{array}{l}\text { Cat. } \\
{[\mathrm{mol} \%]}\end{array}$} & \multirow{2}{*}{$\frac{\mathrm{LiNTf}_{2}}{\mathrm{Lmol}_{\mathrm{Bu}}}$} & \multicolumn{2}{|c|}{$\frac{\text { [2], } \mathrm{LiNTf}_{2}, \mathrm{CO}}{\text { solvent, } \mathrm{T}, \mathrm{t}}$} & \multicolumn{2}{|r|}{$\mathrm{Bu}$} & \multicolumn{2}{|c|}{$+\mathrm{CO}_{2}$} & \multirow[b]{2}{*}{$\begin{array}{l}\text { Isomer }^{\mathrm{b}} \\
{[\%]}\end{array}$} \\
\hline & & & $\begin{array}{l}\mathrm{CO} \\
{[\text { bar] }}\end{array}$ & Solvent & $\begin{array}{l}\text { Temp } \\
{\left[{ }^{\circ} \mathrm{C}\right]}\end{array}$ & $\begin{array}{l}\text { Time } \\
\text { [h] }\end{array}$ & $\begin{array}{l}\text { Conv. }{ }^{b} \\
{[\%]}\end{array}$ & $\begin{array}{l}\text { Yield }^{b} \\
{[\%]}\end{array}$ & \\
\hline 1 & 5 & -- & 10 & $\mathrm{C}_{6} \mathrm{D}_{6}$ & 80 & 24 & 0 & 0 & \\
\hline 2 & -- & 30 & 10 & $\mathrm{C}_{6} \mathrm{D}_{6}$ & 80 & 24 & 0 & 0 & \\
\hline 3 & 1 & 6.0 & 10 & $\mathrm{C}_{6} \mathrm{D}_{6}$ & 80 & 24 & 32 & 32 & \\
\hline 4 & 2.5 & 15 & 10 & $\mathrm{C}_{6} \mathrm{D}_{6}$ & 80 & 24 & 81 & 70 & \\
\hline 5 & 5 & 30 & 10 & $\mathrm{C}_{6} \mathrm{D}_{6}$ & 80 & 24 & 100 & 97 & 2 \\
\hline 6 & 5 & 30 & 10 & Tol-d 8 & 80 & 24 & 92 & 91 & \\
\hline 7 & 5 & 30 & 10 & THF- $\mathrm{d}_{8}$ & 80 & 24 & 7 & 3 & -- \\
\hline
\end{tabular}




\begin{tabular}{llllllllll}
8 & 5 & 30 & 2.0 & $\mathrm{C}_{6} \mathrm{D}_{6}$ & 80 & 24 & 83 & 79 & 4 \\
9 & 5 & 30 & 5.9 & $\mathrm{C}_{6} \mathrm{D}_{6}$ & 80 & 24 & 94 & 90 & 4 \\
10 & 5 & 30 & 15 & $\mathrm{C}_{6} \mathrm{D}_{6}$ & 80 & 24 & 94 & 91 & 3 \\
11 & 5 & 30 & 10 & $\mathrm{Tol}^{-} \mathrm{d}_{8}$ & 100 & 8 & 100 & 93 & \\
12 & 5 & 30 & 10 & $\mathrm{Tol}-\mathrm{d}_{8}$ & 120 & 0.5 & 96 & 92 & \\
13 & 5 & 30 & 10 & $\mathrm{C}_{6} \mathrm{D}_{6}$ & $\mathrm{rt}$ & 168 & 6 & 6 & \\
\hline
\end{tabular}

[a] reaction carried out in a pressure NMR tube (Wilmad) at 10 bar $\mathrm{CO}$ and $0.2 \mathrm{M}$ epoxide concentration. [b] from ${ }^{1} \mathrm{H}$ NMR calibrated to $1,3,5$-trimethoxybenzene as internal standard.

We screened a broad range of substrates and found that terminal epoxides react most readily (Figure 2). The reaction under the optimized conditions works very well for aliphatic, terminal epoxides (3a-3e) including benzyl epoxide (3k) (no isomerization to methyl styrene is observed), and 1,1-disubstituted epoxides (3f), whereas internal epoxides (3g-3j) are much harder to deoxygenate as well as terminal epoxides bearing functional groups (3I-3y). In case of styrene oxide (3n) the formation of $28 \%$ of benzyl aldehyde indicates a Lewis acid catalyzed epoxide isomerization as side reaction. The use of $\mathrm{LiBr}$ (solubilized with 4 eq of tetrahydrofuran) instead of $\mathrm{LiNTf}_{2}$, which circumvented this reaction in the nucleophilic epoxide isomerization, ${ }^{[31]}$ did not have any beneficial effect. Although the amount of the aldehyde by-product could be reduced pronouncedly using $\mathrm{LiBr}$ or Lil, the reaction did not go to completion due to deactivation of the catalyst by formation of $\left[\operatorname{Ir}(\right.$ bimca $\left.)(\mathrm{CO}) \mathrm{X}_{2}\right](\mathrm{X}=\mathrm{Br}, \mathrm{I})$ (see Supporting Information). Most striking is the stereochemistry when 1,2-disubstituted epoxides are reacted: deoxygenation of cis epoxide cis-3j led to full retention of the configuration in olefin cis-4j. Slow subsequent isomerization of the olefin into the more stable trans-butene, however, can occur towards the end of the reaction. Respectively, trans-butene oxide (trans-3j) is converted into trans-butene (trans-4j), albeit at a slower reaction rate. The opposite selectivity, inversion of the configuration, is observed with the doubly ester functionalized substrates cis-3z and trans-3z. Although the reaction is extremely slow at $80^{\circ} \mathrm{C}$ in benzene $(10 \mathrm{~d})$ it proceeds with moderate yields and low isomerization. At $120{ }^{\circ} \mathrm{C}$ the epoxy succinate cis-3z reacted to diethyl fumarate (trans-4z) in $32 \%$ yield and the trans epoxide trans-3z to diethyl maleate (cis-4z) in $25 \%$ already after $24 \mathrm{~h}$ and with still good selectivity.
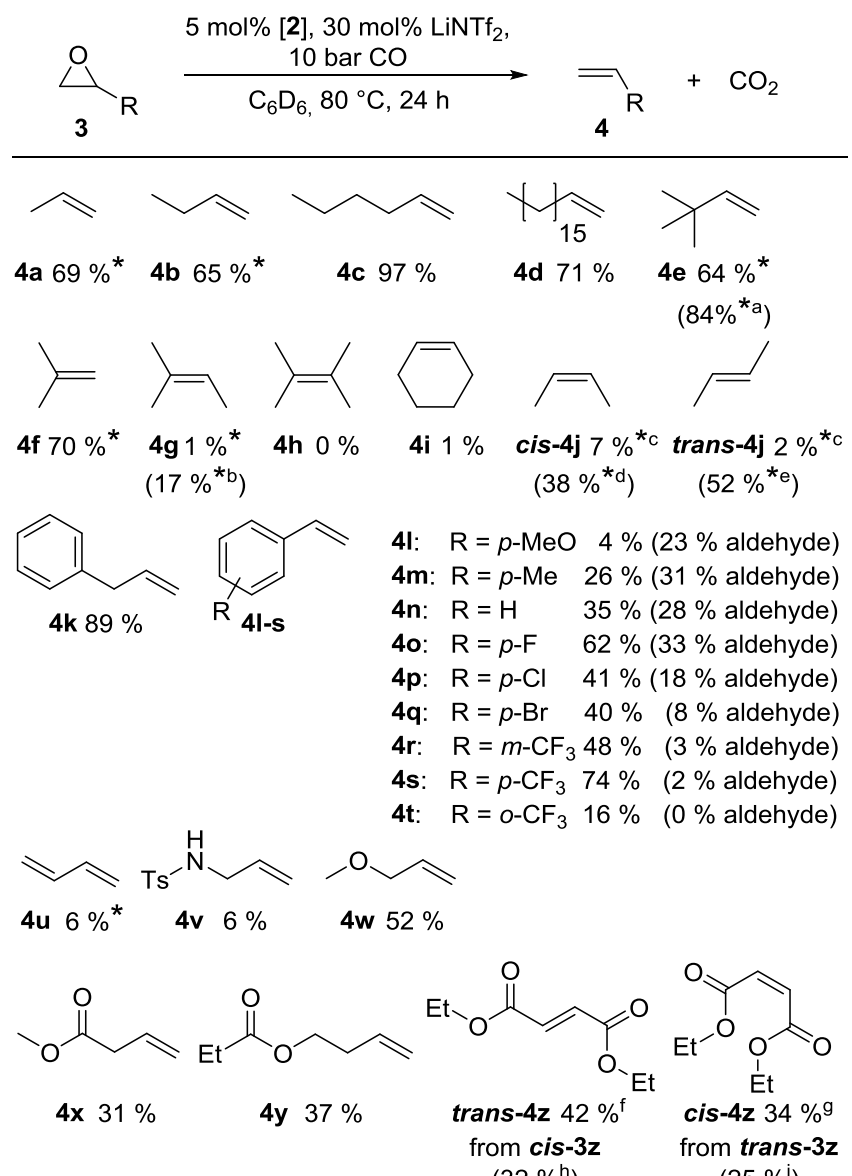

Figure 2. Chemo- and stereoselective deoxygenation of various epoxides. Reactions were carried out in a medium-wall NMR tube with pressure valve (Wilmad) at $0.2 \mathrm{M}$ epoxide concentration. Yields were determined by ${ }^{1} \mathrm{H}$ NMR spectroscopy calibrated to $1,3,5$-trimethoxybenzene as internal standard after release of the overpressure. ${ }^{*}$ indicates the ${ }^{1} \mathrm{H}$ NMR yield of the dissolved amount of the gaseous reaction product, measured under $\mathrm{CO}$ pressure. [a] $120^{\circ} \mathrm{C}, 24 \mathrm{~h}$; [b] $120{ }^{\circ} \mathrm{C}$ 
$96 \mathrm{~h} ;$ [c] $224 \mathrm{~h} ;$ [d] $120^{\circ} \mathrm{C}, 72 \mathrm{~h}, 11 \%$ trans-4j; [e] $120^{\circ} \mathrm{C}, 72 \mathrm{~h}, 2 \%$ cis-4j; [f] $240 \mathrm{~h}, 9 \%$ cis-3z; [g] $240 \mathrm{~h} ; 8 \%$ trans-3z; [h] $120{ }^{\circ} \mathrm{C}, 48 \mathrm{~h}, 7 \%$ cis-3z; [i] $120{ }^{\circ} \mathrm{C}$, $48 \mathrm{~h}, 16 \%$ trans-3z.

The selectivity of this reaction can be explained with a substrate-dependant change in the epoxide activation mechanism (vide infra) from oxidative addition in the case of alkyl epoxides to an $\mathrm{S}_{\mathrm{N}} 2$ mechanism for the C-O bond activation in the case of ethyl carboxylates $(\mathbf{3 z})$ (vide infra).

\section{Mechanistic investigations.}

First, we tested whether a second CO ligand coordinates to 2 to form an 18 VE complex 2+CO. However, under 10 bar of CO no change of the ${ }^{1} \mathrm{H}$ NMR signals of 2 was observed. Moreover, in the ${ }^{13} \mathrm{C}$ NMR spectrum we see two separate CO signals, one for the iridium complex 2 and one for free CO. This confirms that no fast exchange of the CO ligand on the NMR timescale occurs. In the IR spectrum (toluene) at atmospheric pressure of $\mathrm{CO}$, neither a shift nor an additional band was observed, and under $\mathrm{CO}$ atmosphere only complex 2 crystallized out. Therefore, we conclude that the 16 VE complex 2 is the catalytic active species. Also for rhodium complex 1 we had not observed any exchange of the $\mathrm{CO}$ ligand by ${ }^{13} \mathrm{CO}$ under 3 bar, neither under UV light nor by heating at 60 $70{ }^{\circ} \mathrm{C}^{[26]}$.

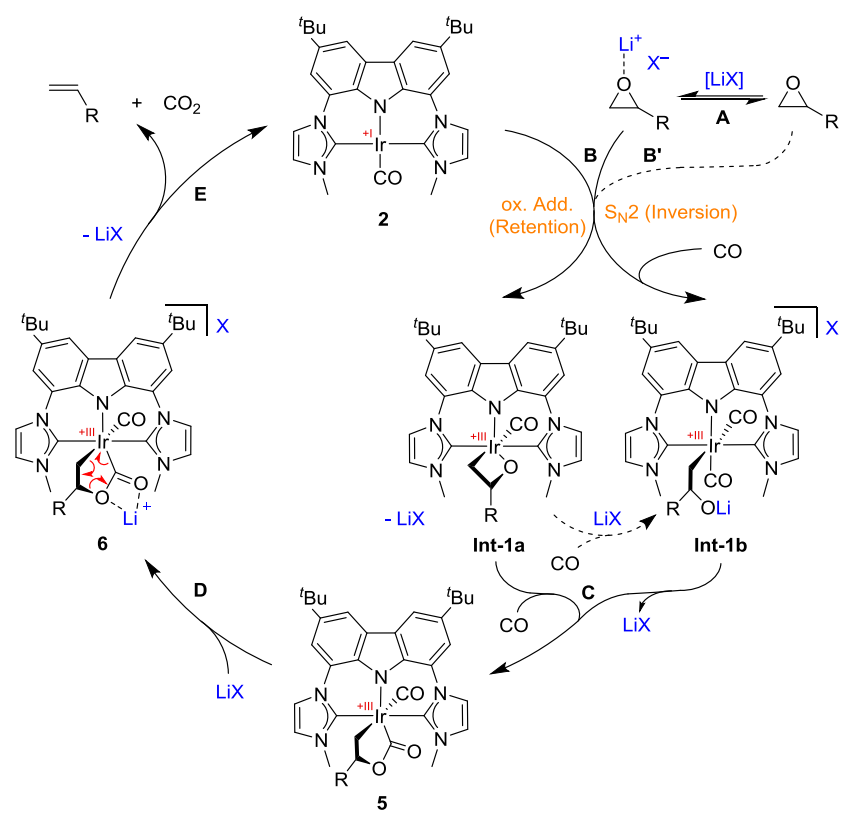

Scheme 2. Proposed mechanism of the deoxygenation of epoxides with CO catalysed by iridium complex 2 . The Lewis acid co-catalyst is necessary to activate the epoxide (A) as well as to induce the decarboxylation (D, E). The involvement of Int-1a depends on the substrate: 1,2-dialkyl epoxides react to Int-1a in an oxidative addition of the epoxide $\mathrm{C}-\mathrm{O}$ bond, while cis- and trans-1,2-diethylcarboxyl epoxide get activated through an $\mathrm{S}_{\mathrm{N}} 2$ mechanism.

The first step of the catalytic cycle is the cleavage of the C-O bond of the epoxide (B). This step requires pre-activation of the epoxide by the Lewis acid (step A), as it is already known from the nucleophilic epoxide isomerization with rhodium catalyst $\mathbf{1}$ and its congeners. ${ }^{[28,31,32]}$ Although the complete catalytic cycle does not operate in absence of the Lewis acid (Table 2, entry 1), the C-O bond cleavage of propylene oxide occurs at $80^{\circ} \mathrm{C}$, albeit extremely slowly (B'). We took advantage of this observation and reacted 2 with propylene oxide (3a) and 10 bar of $\mathrm{CO}$ at $80^{\circ} \mathrm{C}$ for 10 days, and were able to isolate intermediate $5 \mathbf{a}$. Due to the presence of the $\mathrm{CO}$ atmosphere, further reaction to acetone or a hydridoalkyl complex ${ }^{[33]}$ is blocked. The identity of $\mathbf{5 a}$, which contains a hitherto unprecedented 2-irida- $y$-lactone moiety, was proven by spectroscopic methods. Due to the chiral center at the epoxide the symmetry of the complex is reduced and 8 signals for the aromatic $\mathrm{H}$ atoms and two for the $\mathrm{N}$-methyl groups are observed. The two signals of the diastereomeric methylene protons of the ring opened epoxide are detected at 1.71 and $1.80 \mathrm{ppm}$ and the methine signal at 3.92 $\mathrm{ppm}$. From the ${ }^{13} \mathrm{C}$ NMR spectrum further evidence for formation of the CO complex 5a was obtained (172.6 $\mathrm{ppm}\left(\mathrm{IrCO} \mathrm{R}_{2}\right), 182.8$ (CO), $78.8\left(\mathrm{O}-\mathrm{CH}\left(\mathrm{CH}_{3}\right)-\right)$, and $27.6\left(\mathrm{Ir}-\mathrm{CH}_{2}\right) \mathrm{ppm}$. The IR spectrum (ATR) confirms this with characteristic bands at $2014(\mathrm{CO})$ and $1630 \mathrm{~cm}^{-1}\left(\mathrm{IrCO}_{2} \mathrm{R}\right)$. When monitoring the catalytic reaction NMR-spectroscopically (with Lewis acid) at $60{ }^{\circ} \mathrm{C}$ over a period of $23 \mathrm{~h}$, this intermediate can also be detected. Its concentration reaches quickly a maximum of $5 \mathrm{~mol} \%$ and slowly declines during the course of the reaction (see Supporting Information). This shows, that the epoxide activation step $\mathbf{A}$ and the decarboxylation step $\mathbf{E}$ have about roughly the same reaction rate under the applied conditions for this substrate.

The reaction of cis- and trans-1,2-dialkyl-substituted epoxide (cis-3j, trans-3j) led to retention of the configuration in the respective products (cis-4j and trans-4j) and to inversion in the case of 1,2-diethylcarboxylate-substituted epoxides (3z). As an epoxide opening that follows an $\mathrm{S}_{\mathrm{N}} 2$ mechanism would lead to inversion of the configuration in a possible intermediate Int-1b, we conclude that the 
activation step B proceeds via oxidative addition under C-O bond cleavage to the iridaoxetane ${ }^{[10,11]}$ Int-1a with the substrates cis-3j and trans-3j. This is followed by CO induced migration of the alkoxide from Ir to a CO ligand to form $\mathbf{5 j}$. Under the applied conditions, Int-1b could also be formed from Int-1a by Lewis acid ring opening followed by CO coordination and lactone formation by nucleophilic addition of the alkoxide to $\mathrm{CO}$ to form $\mathbf{5 j}$ without change of the configuration. Attempts to detect $\mathbf{5 j}$ from 1,2 -dialkylsubstituted epoxides 3j failed, as these substrates do not react without presence of the Lewis acid. During the catalytic conditions, no intermediate was observed which counts for the oxidative addition $\mathbf{B}$ to be the rate-determining step with these substrates. In case of the ester functionalized epoxides $\mathbf{3 z}$ the intermediate $\mathbf{5 z}$ was obtained much easier without Lewis acid compared to propylene oxide (3a) as a substrate. The ${ }^{3} J_{\mathrm{HH}}$ coupling between the methine protons of the metallalactone moiety of trans-5z (obtained from cis-3z) of $6.8 \mathrm{~Hz}$ and that of cis- $\mathbf{5 z}$ (obtained from trans-3z) of $3.2 \mathrm{~Hz}$, confirm the inversion of the configuration. Proof for the configuration as well as for the formation of the 2-irida-y-lactone was obtained from the X-ray crystal structure analyses (Figure 3).
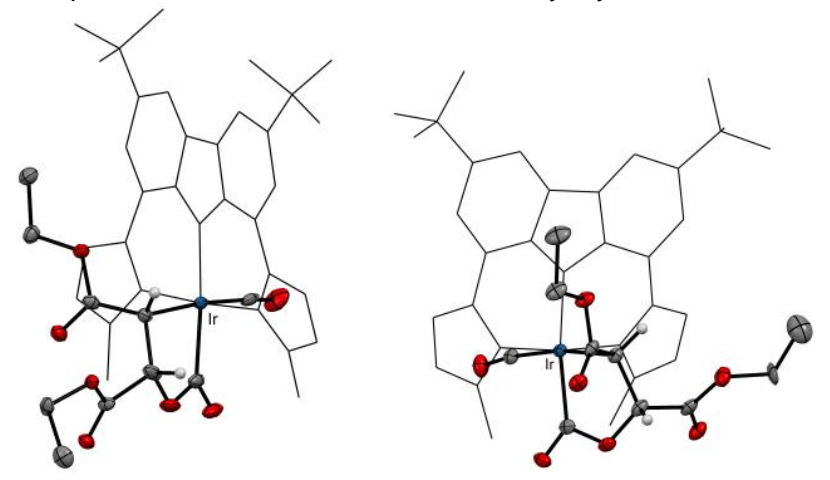

Figure 3. Molecular structure of the isolated intermediates cis-5z from (trans-3z) (left) and trans-5z (from cis-3z) (right) from reactions of 2 and $\mathbf{3 z}$ without added Lewis acid. Atoms are shown with anisotropic atomic displacement parameters at the $50 \%$ probability level. Hydrogen atoms (except for the iridacycle) as well as co-crystallized benzene molecules are omitted for clarity.

An inversion of the configuration was also observed by Dowd and Kang, using stoichiometric amounts (referring to $\mathrm{CO})$ of $\mathrm{Co}_{2}(\mathrm{CO})_{8}$ in the reaction with $\mathbf{3 z} .^{[12]}$ They suggested an analogous intermediate. Their reaction occurred already at room temperature, albeit in neat epoxide. $S_{N} 2$ reactions with $R h(I)$ and $\operatorname{lr}(I)$ complexes are typically observed in the oxidative addition of alkyl iodide in the Monsanto or Cativa acetic acid process, ${ }^{[34]}$ while metallaoxetane formation from oxiranes with $\operatorname{Rh}(\mathrm{I})$ and $\operatorname{Ir}(\mathrm{I})$ was investigated by Milstein and coworkers. ${ }^{[3,35]}$ In our case, it seems energetically favored for iridium complex $\mathbf{2}$ to open the electron poor epoxide $\mathbf{3 z}$ in an $\mathrm{S}_{\mathrm{N}} 2$ fashion and the more electron rich internal epoxide $3 \mathbf{j}$ by oxidative addition of the $\mathrm{C}-\mathrm{O}$ bond.

The accumulation of intermediate $\mathbf{5}$ in absence of a Lewis acid also means that the subsequent decarboxylation step $\mathbf{E}$ requires the presence of a Lewis acid as well. To confirm this, we heated intermediate $5 \mathrm{a}$ in $\mathrm{C}_{6} \mathrm{D}_{6}$ (without $\mathrm{CO}$ atmosphere) up to $80^{\circ} \mathrm{C}$ and found no $\mathrm{CO}_{2}$ elimination, while addition of the Lewis acid led to slow formation of the signals of propene (4a) already at room temperature along with the signals of 2 . When stoichiometric amounts of $\mathrm{LiNTf}_{2}$ were added, we observe a slight shift in the ${ }^{1} \mathrm{H}$ NMR signals, which is most pronounced for the $\mathrm{N}-\mathrm{CH}_{3}$ and the adjacent imidazole signals (see Supporting Information Figure S1). Therefore, we propose formation of Lewis acid adduct $\mathbf{6}$ (step D) which is mandatory for the $\mathrm{CO}_{2}$ elimination (step E). In the case of the isolated intermediates cis- $5 \mathbf{z}$ and trans-5z the $\mathrm{CO}_{2}$ elimination step required even heating to $60^{\circ} \mathrm{C}$ and thus is the rate limiting step using these substrates.

As $\beta$-lactones are known to easily eliminate $\mathrm{CO}_{2}$ under elevated temperatures or Lewis acidic conditions, the reductive elimination of $\beta$-lactones from intermediate 6 and subsequent $\mathrm{CO}_{2}$ elimination could also be a possible way to obtain the olefin. However, as we observed olefin formation from intermediate $\mathbf{5 a}$ in the presence of a Lewis acid already at room temperature without detecting any signals of a $\beta$-lactone, we are convinced that the olefins are formed by direct $\mathrm{CO}_{2}$ elimination from intermediate 6 . In addition, literature known syntheses of $\beta$-lactones often proceed under elevated temperatures as well. Moreover, the reverse reaction, the oxidative addition of $\beta$-lactones, is also not observed. Milstein and coworkers have shown that electron rich $16 \mathrm{VE}$ iridium(I) complexes oxidatively add $\beta$-propriolactones readily at low temperatures by $\mathrm{C}_{\text {alkyl}} \mathrm{O}$ bond cleavage, thus forming 4 -irida-y-lactones (Scheme 3, bottom). ${ }^{[36]} \mathrm{C}-\mathrm{C}_{\text {acyl }}$ bond activation, which would form 2-irida-y-lactones (like in 5), have not been observed.

To answer the question about the particularity of our systems 1 and 2 in comparison with $\mathrm{Co}_{2} \mathrm{CO}_{8}$ catalyzed CO/epoxide reactions that produce polymers or $\beta$-lactones is the fact that no migratory insertion step of the alkyl group to the carbonyl ligand is involved after epoxide opening as the molecular structure of intermediate 5 revealed. Fast $\mathrm{CO}$ migratory insertion after epoxide opening and C-O bond formation to obtain a 2-metallaoxolan-3-one (Scheme 3, left) is usually considered the key step in the formation of $\beta$ lactones. ${ }^{[11,30]}$ In contrast, a nucleophilic attack of the alkoxide O-atom at the CO ligand forms the 2-irida-y-lactone in our case (Scheme 3, right). This can be explained with a stronger Ir-alkyl bond. It is known that migratory insertion to form acyl ligands occurs slowly in iridium complexes and is e.g., the rate limiting step in the Cativa process. ${ }^{[37,38]}$ 


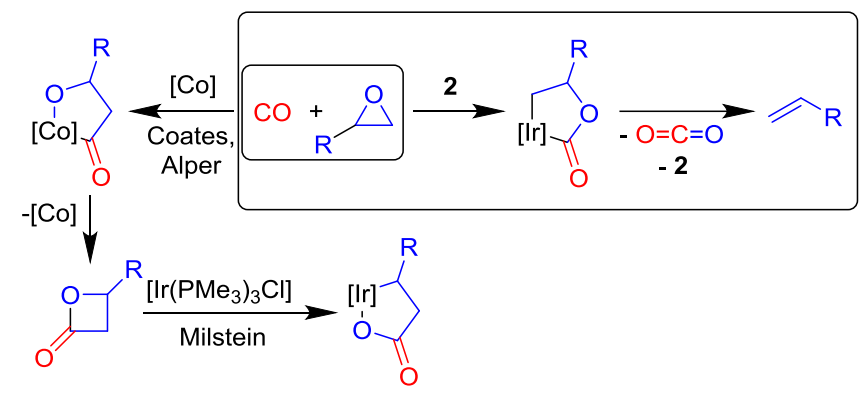

Scheme 3. Literature known formation of $\beta$-lactones (left) and their C-O activation with iridium(I) complexes (bottom). The deoxygenation of epoxides (right, this work) proceeds via a new isomeric iridalactone which does not reductively eliminate $\beta$-lactones.

\section{Conclusion}

In summary we presented a new homogeneous catalyzed deoxygenation of epoxides that uses CO directly as a traceless and environmentally benign deoxygenation agent. Especially terminal alkyl epoxides react smoothly and without significant isomerization to the internal olefins. Internal epoxides react under either retention or inversion of the configuration, depending on their substituents. This can be explained by two different modes of the epoxide opening. Either by an oxidative addition of the epoxy-CO bond which leads to retention of the configuration or by an $\mathrm{S}_{\mathrm{N}} 2$-pathway under inversion of the configuration. Various iridalactones 5 were isolated and in some cases structurally characterized. Under stoichiometric conditions, the coordination of the Lewis acid to $\mathbf{5}$ forming 6 is observed, from which the olefin is released. Thus, the role of the Lewis acid is not only pre-activation of the epoxide, but also inducing the $\mathrm{CO}_{2}$ elimination to produce the product olefin.

\section{Experimental Section}

General Information. Unless otherwise stated, all reactions were carried out under an argon atmosphere in dried and degassed solvents using Schlenk technique. Toluene, pentane, were purchased from Sigma Aldrich and dried using an MBraun SPS-800 solvent purification system. All lithium salts used were obtained from commercial suppliers, dried in vacuum and used without further purification. Chemicals from commercial suppliers were degassed through freeze-pump-thaw cycles prior to use. Carbon monoxide was purchased from Westfalen with a purity of $99.97 \%$. High pressure NMR scale experiments were performed in heavy or medium wall pressure valve NMR tubes (Wilmad). ${ }^{1} \mathrm{H}$ NMR spectra of catalytic experiments were recorded with an increased delay time $d_{1}$ of $60 \mathrm{~s}$ to insure reliable integration values. See Supporting Information for the numbering scheme of the compounds.

Synthesis of the catalyst [Ir(bimcaMe)(CO)] (2). Benzyl potassium (58.6 mg, $450 \mu \mathrm{mol})$ and $\left[\operatorname{lr}(\mathrm{acac})(\mathrm{CO})_{2}\right](52.1 \mathrm{mg}, 150 \mu \mathrm{mol})$ were added to a suspension of HbimcaMe.2HI (104.3 mg, $150 \mu \mathrm{mol})$ in $12 \mathrm{~mL}$ of toluene at room temperature and stirred for $24 \mathrm{~h}$. The resulting yellow suspension was filtered, and the filtrate dried in vacuo to obtain the desired product as a yellow solid $(96 \mathrm{mg}, 91 \%)$. ${ }^{1} \mathrm{H} \mathrm{NMR}\left(400 \mathrm{MHz}, \mathrm{C}_{6} \mathrm{D}_{6}\right)=1.54(\mathrm{~s}, 18 \mathrm{H}, \mathrm{H}-11)$, 3.81 (s, 6H, H-14), 6.14 (d, J = 2.2 Hz, 2H, H-2), 7.31 (d, J=2.2 Hz, 2H, H-4), 7.64 (d, J = 1.6 Hz, 2H, H-4'), 8.48 (d, J = 1.6 Hz, 2H, H-5'). The NMR data in thf- $\mathrm{d}_{8}$ is identical to that of a sample obtained with a Li-base ${ }^{[27]}$ however, using benzyl potassium gives a much cleaner reaction.

General procedure for the catalytic deoxygenation. 2 ( $3.3 \mathrm{mg}, 5.0 \mu \mathrm{mol})$, lithium bis(trifluoromethylsulfonyl)imide (8.6 mg, $30 \mu \mathrm{mol})$ and a certain amount of 1,3,5-trimethoxybenzene as internal standard were dissolved in $0.5 \mathrm{~mL}$ of benzene- $\mathrm{d}_{6}$ or toluene- $\mathrm{d}_{8}$ in a pressure NMR tube. Then $100 \mu \mathrm{mo}$ of epoxide were added and the NMR-ampule was pressurized with 10 bar $\mathrm{CO}$, and heated in an oil bath at $80^{\circ} \mathrm{C}$, if not otherwise noted. The yield was determined via ${ }^{1} \mathrm{H}$ NMR.

Synthesis of 5a. Synthesis of $5 a .2(6.6 \mathrm{mg} 10 \mu \mathrm{mol})$ and epoxypropane $(1.4 \mu \mathrm{L}, 20 \mu \mathrm{mol})$ were dissolved in $0.5 \mathrm{~mL}$ of $\mathrm{C}_{6} \mathrm{D}_{6}$ in a pressure $\mathrm{NMR}$ tube and pressurized with 10 bar CO. The reaction mixture was heated to $80{ }^{\circ} \mathrm{C}$ for $10 \mathrm{~d}$. The solvent was evaporated and the residue extracted with $\mathrm{DCM}$ After concentration do dryness the residue was was[hed with pentane to obtain 5a as a pale yellow solid (Yield: NMR: $89 \%$; isolated: 1.6 mg, $23 \%$ ). ${ }^{1} \mathrm{H}$ NMR $\left(\mathrm{C}_{6} \mathrm{D}_{6}, 500 \mathrm{MHz}\right): \delta=1.27\left(\mathrm{~d},{ }^{3} \mathrm{~J}_{\mathrm{HH}}=6.0 \mathrm{~Hz}, 3 \mathrm{H}, \mathrm{H}-20\right), 1.50(\mathrm{~s}, 9 \mathrm{H}, \mathrm{H}-11), 1.51(\mathrm{~s}, 9 \mathrm{H}, \mathrm{H}-13), 1.71\left(\mathrm{dd},{ }^{2,3} J_{\mathrm{HH}}=11.0,5.8 \mathrm{~Hz}, 1 \mathrm{H}, \mathrm{H}-19\right), 1.80$ $\left(\mathrm{dd},{ }^{2,3} J_{\mathrm{HH}}=11.0 \mathrm{~Hz}, 11.0 \mathrm{~Hz}, 1 \mathrm{H}, \mathrm{H}-19\right), 3.77(\mathrm{~s}, 3 \mathrm{H}, \mathrm{H}-14), 3.89(\mathrm{~s}, 3 \mathrm{H}, \mathrm{H}-15), 3.92\left(\mathrm{ddq},{ }^{3} J_{\mathrm{HH}}=11.0,5.8 \mathrm{~Hz}, 6.0 \mathrm{~Hz}, 1 \mathrm{H}, \mathrm{H}-18\right), 5.91\left(\mathrm{~d},{ }^{3} J_{\mathrm{HH}}=2.2\right.$ $\mathrm{Hz}, 1 \mathrm{H}, \mathrm{H}-4^{\prime}$ or $\left.9^{\prime}\right), 5.93\left(\mathrm{~d},{ }^{3} J_{\mathrm{HH}}=2.2 \mathrm{~Hz}, 1 \mathrm{H}, \mathrm{H}-4^{\prime}\right.$ or $\left.9^{\prime}\right), 7.17\left(\mathrm{~d},{ }^{3} J_{\mathrm{HH}}=2.2 \mathrm{~Hz}, 1 \mathrm{H}, \mathrm{H}-5^{\prime}\right.$ or $\left.10^{\prime}\right), 7.20\left(\mathrm{~d},{ }^{3} J_{\mathrm{HH}}=2.2 \mathrm{~Hz}, 1 \mathrm{H}, \mathrm{H}_{-} 5^{\prime}\right.$ or $\left.10^{\prime}\right), 7.42\left(\mathrm{~d},{ }^{4} J_{\mathrm{HH}}=\right.$ $1.5 \mathrm{~Hz}, 1 \mathrm{H}, \mathrm{H}-2$ or 7$), 7.43\left(\mathrm{~d},{ }^{4} \mathrm{~J}_{\mathrm{HH}}=1.5 \mathrm{~Hz}, 1 \mathrm{H}, \mathrm{H}-2\right.$ or 7$), 8.37\left(\mathrm{~d},{ }^{4} \mathrm{~J}_{\mathrm{HH}}=1.5 \mathrm{~Hz}, 1 \mathrm{H}, \mathrm{H}-4\right.$ or 5$), 8.38\left(\mathrm{~d},{ }^{4} \mathrm{~J}_{\mathrm{HH}}=1.5 \mathrm{~Hz}, 1 \mathrm{H}, \mathrm{H}-4 \mathrm{or} 5\right) .{ }^{13} \mathrm{C} \mathrm{NMR}\left(\mathrm{C}_{6} \mathrm{D}_{6}\right.$, $125 \mathrm{MHz}): \delta=23.7$ (C20), 27.6 (C19), 32.8 (C11 or C13), 35.3 (C10 or C12), 40.6 (C15), 41.1 (C14), 78.8 (C18), 110.7, 110.8 (C2, C7), 115.8, 116.0 (C4, C5), 117.1, 117.1 (C5', C10'), 124.7 (C4'), 125.1 (C1+C8), 125.3 (C9'), 128.0 (C4a+5a), 134.6, 135.9 (C1a, C8a), 138.8, 138.9 (C3, C6), 147.5

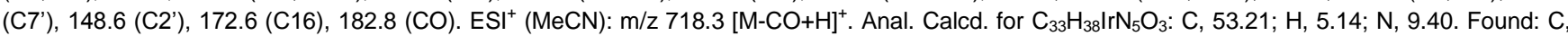
53.27; H, 5.24; N, 9.52. IR (ATR, $\left.\mathrm{cm}^{-1}\right): 2014$ (m, CO), 1630 (w, lactone).

Synthesis of the Intermediates cis- and trans-5z. 2 (9.9 mg, $15 \mu \mathrm{mol})$ and $2.8 \mathrm{mg}(15 \mu \mathrm{mol})$ of either cis- or trans-diethyl epoxy succinate (3z) were dissolved in $0.5 \mathrm{~mL}$ of $\mathrm{C}_{6} \mathrm{D}_{6}$ in a pressure NMR tube and pressurized with 10 bar $\mathrm{CO}$. The reaction mixture was heated to $80{ }^{\circ} \mathrm{C}$ for $1 \mathrm{~d}$. Single crystals suitable for $\mathrm{X}$-ray diffraction were obtained by evaporation of the solvent at room temperature.

Cis-5z: ${ }^{1} \mathrm{H}$ NMR (Tol-d $\left.8,600 \mathrm{MHz}\right): \delta=-0.11$ (t, $\left.J=7.2 \mathrm{~Hz}, 3 \mathrm{H}, \mathrm{H}-29\right), 0.87$ (t, J=7.0 Hz, 3H, H-24), 1.46 (s, 9H, H-11), 1.49 (s, 9H, H-13), 2.43 (dq, J $=10.5,7.2 \mathrm{~Hz}, 1 \mathrm{H}, \mathrm{H}-28), 3.15(\mathrm{dq}, J=10.5,7.2 \mathrm{~Hz}, 1 \mathrm{H}, \mathrm{H}-28), 3.44(\mathrm{~d}, J=6.8 \mathrm{~Hz}, 1 \mathrm{H}, \mathrm{H}-19), 3.78(\mathrm{~s}, 3 \mathrm{H}, \mathrm{H}-14 / 15), 3.85(\mathrm{dq}, J=10.9,7.0 \mathrm{~Hz}, 1 \mathrm{H}, \mathrm{H}-$ 23), 4.07 (dq, J=10.9, $7.0 \mathrm{~Hz}, 1 \mathrm{H}, \mathrm{H}-23$ ), 4.09 (s, 3H, H-14/15), 4.25 (d, J = 6.8 Hz, 1H, H-18), 6.33 (s, 2H, H-5' and 10'), 7.42 (d, J=1.7 Hz, 1H, H-4 or $\left.9^{\prime}\right), 7.47(\mathrm{~s}, 2 \mathrm{H}, \mathrm{H}-4 / 5$ or $2 / 7), 7.49\left(\mathrm{~d}, J=1.7 \mathrm{~Hz}, 1 \mathrm{H}, \mathrm{H}-4^{\prime}\right.$ or $\left.9^{\prime}\right), 8.32(\mathrm{~d}, J=1.1 \mathrm{~Hz}, 1 \mathrm{H}, \mathrm{H}-4 / 5 \mathrm{or} 2 / 7), 8.32(\mathrm{~d}, J=1.1 \mathrm{~Hz}, 1 \mathrm{H}, \mathrm{H}-4 / 5 \mathrm{or} 2 / 7) .{ }^{13} \mathrm{C}$ NMR (Tol-d $8,151 \mathrm{MHz}): \delta=13.0$ (C29), 14.6 (C24), 32.7, 32.8 (C11, C13), 35.3 (C10+C12), 39.4 (C19), $41.2,41.7$ (C14, C15), 59.1 (C28), 60.5 (C23), 
79.8 (C18), 110.7, 110.8, 115.6, 116.2 (C2+C4+C5+C7), 116.4, 117.9 (C5', C10'), 124.2, 124.8 (C1+C8 or C4a+C5a), 125.8, 127.0 (C4'+C9'), 127.9, $128.0 \mathrm{C} 1+\mathrm{C} 8$ or C4a+C5a), 134.1, $134.9(\mathrm{C} 1 \mathrm{a}+\mathrm{C} 8 \mathrm{a}), 139.0$ (C3+C6), 144.3, 144.7 (C2', C7'), 168.8 (C16), 170.4 (C21), 179.3 (CO), 180.3 (C26). ESI (MeCN): m/z $875.28\left[\mathrm{M}^{+}, 848.31[\mathrm{M}-\mathrm{CO}+\mathrm{H}]^{+}\right.$. IR $\left(\mathrm{ATR}, \mathrm{cm}^{-1}\right): 2034(\mathrm{~s}, \mathrm{CO}), 1747$ (m, ester), 1691 (m, ester), $1645(\mathrm{~m}, \mathrm{lactone})$

Trans-5z: ${ }^{1} \mathrm{H}$ NMR $\left(\mathrm{C}_{6} \mathrm{D}_{6}, 400 \mathrm{MHz}\right): \delta=-0.17(\mathrm{t}, J=7.2 \mathrm{~Hz}, 3 \mathrm{H}, \mathrm{H}-29), 0.76(\mathrm{t}, J=7.2 \mathrm{~Hz}, 3 \mathrm{H}, \mathrm{H}-24), 1.47(\mathrm{~s}, 9 \mathrm{H}, \mathrm{H}-11 / 13), 1.48(\mathrm{~s}, 9 \mathrm{H}, \mathrm{H}-11 / 13)$, 2.36 (dq, $J=10.6,7.1 \mathrm{~Hz}, 1 \mathrm{H}, \mathrm{H}-28$ ), 3.20 (dq, $J=10.5,7.3 \mathrm{~Hz}, 1 \mathrm{H}, \mathrm{H}-28$ ), 3.58 (dq, $J=10.4,7.1 \mathrm{~Hz}, 1 \mathrm{H}, \mathrm{H}-23), 3.60$ (d, J=3.2 Hz, $1 \mathrm{H}, \mathrm{H}-19$ ), 3.76 (dq, $J=10.7,7.1 \mathrm{~Hz}, 1 \mathrm{H}, \mathrm{H}-23), 4.04$ (s, 3H, H-14/15), 4.05 (s, 3H, H-14/15), 5.46 (d, J = 3.2 Hz, 1H, H-18), $6.12\left(\mathrm{~d}, J=2.0 \mathrm{~Hz}, 1 \mathrm{H}, \mathrm{H}-4^{\prime} / 9^{\prime}\right), 6.16(\mathrm{~d}, J$ $\left.=1.9 \mathrm{~Hz}, 1 \mathrm{H}, \mathrm{H}-4^{\prime} / 9^{\prime}\right), 7.14$ (d, J=2.1 Hz, 1H, H-5'/10'), 7.37 (d, J=2.1 Hz, 1H, H-5'/10'), $7.41(\mathrm{~d}, J=1.1 \mathrm{~Hz}, 1 \mathrm{H}, \mathrm{H}-2 / 7), 7.43(\mathrm{~d}, J=1.1 \mathrm{~Hz}, 1 \mathrm{H}, \mathrm{H}-$ 2/7), $8.36(\mathrm{~d}, J=1.3 \mathrm{~Hz}, 1 \mathrm{H}, \mathrm{H}-4 / 5), 8.38(\mathrm{~d}, J=1.4 \mathrm{~Hz}, 1 \mathrm{H}, \mathrm{H}-4 / 5) .{ }^{13} \mathrm{C} \mathrm{NMR}\left(\mathrm{C}_{6} \mathrm{D}_{6}, 101 \mathrm{MHz}\right): \delta=12.8(\mathrm{C} 29), 14.5(\mathrm{C} 24), 32.8(\mathrm{C} 11+\mathrm{C} 13), 35.3$ (C10+C12), 38.7 (C19), 41.4 (C14+C15), 59.6 (C28), 60.8 (C23), 79.6 (C18), 110.6, 110.7 (C2, C7), 115.7, 115.9 (C4, C5), 116.4, 117.5 (C5', C10'), 124.7, 124.9 (C4', C9'), 125.9, 126.4, 127.9, 128.0 (C1, C8, C4a, C5a), 134.6, 134.8 (C1a, C8a), 139.0 (C3+C6), 142.8, 144.5 (C2', C7'), 168.7 (C16), 173.0 (C21), 181.5, 181.7 (CO, C26). ESI ${ }^{+}(\mathrm{MeCN}): \mathrm{m} / \mathrm{z} 875.28$ [M] $]^{+}, 848.31$ [M-CO+H] $]^{+}$IR (ATR, cm $\left.{ }^{-1}\right): 2035(\mathrm{~s}, \mathrm{CO}), 1738(\mathrm{~m}, \mathrm{ester}), 1683(\mathrm{~m}, \mathrm{ester})$, 1645 (m, lactone).

X-ray Structure Analysis. Data collection was carried out on a Bruker APEX Duo CCD with an Incoatec l $\mu$ S Microsource with a Quazar MX mirror using Mo $\mathrm{K}_{\alpha}$ radiation $(\lambda=0.71073 \AA)$ and a graphite monochromator. Corrections for absorption effects were applied using SADABS. ${ }^{[39]}$ All structures were solved by direct methods using SHELXS and refined using SHELXL. ${ }^{[40]}$ CCDC 1951759 (trans-5z), 1951760 (cis-5z), 1951761 $\left(\left[\operatorname{lr}(\right.\right.$ bimca $\left.\left.)(\mathrm{CO}) \mathrm{Br}_{2}\right]\right)$ and $1951762\left(\left[\operatorname{lr}(\right.\right.$ bimca $\left.\left.)(\mathrm{CO}) \mathrm{I}_{2}\right]\right)$ contain the supplementary crystallographic data. These data can be obtained free of charge from the Cambridge Crystallographic Data Centre at www.ccdc.cam.ac.uk/data_request/cif.

\section{Acknowledgements}

Theo Maulbetsch and Eva Jürgens thank the MWK-BW for a fellowship (Landesgraduiertenförderung). We are grateful to Yingying Tian for providing some of the epoxide starting material and Ronja Jordan for a sample of [Ir(bimca $\left.\left.{ }^{\mathrm{C} 5}\right)(\mathrm{CO})\right]$, to Cäcilia MeichleMössmer for help with the X-ray structure analyses, to Klaus Eichele and Kristina Strohmaier for measuring all NMR samples under CO pressure and to Dominik Brzecki for operating the 600 NMR spectrometer. We also acknowledge help of Fotios Fotakis with catalytic experiments of the styrene oxide substrates.

Keywords: Deoxygenation • Epoxides • Homogeneous Catalysis • Iridium • Pincer Ligands

\section{References}

[1] A. Ambrosi, S. E. Denmark, Angew. Chem., Int. Ed. 2016, 55, 12164-12189.

[2] D. Chusov, B. List, Angew. Chem., Int. Ed. 2014, 53, 5199-5201.

[3] A. A. Tsygankov, M. Makarova, D. Chusov, Mendeleev Commun. 2018, 28, 113-122.

[4] A. P. Moskovets, D. L. Usanov, O. I. Afanasyev, V. A. Fastovskiy, A. P. Molotkov, K. M. Muratov, G. L. Denisov, S. S. Zlotskii, A. F. Smol'Yakov, D. A. Loginov, et al., Org. Biomol. Chem. 2017, 15, 6384-6387.

[5] G. Wittig, W. Haag, Chem. Ber. 1955, 88, 1654-1666.

[6] E. Vedejs, P. L. Fuchs, J. Am. Chem. Soc. 1971, 93, 4070-4072.

[7] E. Vedejs, P. L. Fuchs, J. Am. Chem. Soc. 1973, 95, 822-825.

[8] K. P. Gable, E. C. Brown, Synlett 2003, 2243-2245.

[9] K. P. Gable, E. C. Brown, J. Am. Chem. Soc. 2003, 125, 11018-11026.

[10] K. A. Jørgensen, B. Schioett, Chem. Rev. 1990, 90, 1483-1506.

[11] A. Dauth, J. A. Love, Chem. Rev. 2011, 111, 2010-2047.

[12] P. Dowd, K. Kang, J. Chem. Soc. Chem. Commun. 1974, 384-385.

[13] H. Alper, D. Des Roches, Tetrahedron Lett. 1977, 18, 4155-4158.

[14] J. M. Concellón, E. Bardales, Org. Lett. 2002, 4, 189-191.

[15] M. Mahesh, J. A. Murphy, H. P. Wessel, J. Org. Chem. 2005, 70, 4118-4123.

[16] B. Xiao, Z. Niu, Y.-G. Wang, W. Jia, J. Shang, L. Zhang, D. Wang, Y. Fu, J. Zeng, W. He, et al., J. Am. Chem. Soc. 2015, 137, $3791-3794$.

[17] J. Yu, Y. Zhou, Z. Lin, R. Tong, Org. Lett. 2016, 18, 4734-4737.

[18] H. C. Volger, H. Hogeveen, C. F. Roobeek, Recl. des Trav. Chim. des Pays-Bas 2010, 92, 1223-1231. All reactions in references 18-20 were performed without the presences of $\mathrm{CO}$ gas and in chloroform, which is proposed to act as the deoxygenation agent as phosgene was detected. Although carbonyl containing catalysts (15 or $20 \mathrm{~mol} \%$ of $\left[\mathrm{Rh}(\mathrm{CO})_{2} \mathrm{Cl}_{2}\right.$ ) were used and produced some $\mathrm{CO}_{2}$, full conversion can only be explained with the presence of chloroform.

[19] R. Roulet, J. Wenger, M. Hardy, P. Vogel, Tetrahedron Lett. 1974, 15, 1479-1482.

[20] R. W. Ashworth, C. A. Berchtold, Tetrahedron Lett. 1977, 18, 339-342.

[21] J. E. Ziegler, M. J. Zdilla, A. J. Evans, M. M. Abu-Omar, Inorg. Chem. 2009, 48, 9998-10000.

[22] A. Noujima, T. Mitsudome, T. Mizugaki, K. Jitsukawa, K. Kaneda, Angew. Chem., Int. Ed. 2011, 50, $2986-2989$.

[23] T. Mitsudome, A. Noujima, Y. Mikami, T. Mizugaki, K. Jitsukawa, K. Kaneda, Angew. Chem., Int. Ed. 2010, 49, 5545-5548.

[24] T. Mitsudome, A. Noujima, Y. Mikami, T. Mizugaki, K. Jitsukawa, K. Kaneda, Chem. - Eur. J. 2010, 16, 11818-11821.

[25] K. Kaneda, H. Matsuda, Method for Producing Alkene by Deoxidation of Epoxy Compound, 2010, JP2011236165A.

[26] M. Moser, B. Wucher, D. Kunz, F. Rominger, Organometallics 2007, 26, 1024-1030.

[27] A. Seyboldt, B. Wucher, M. Alles, F. Rominger, C. Maichle-Mössmer, D. Kunz, J. Organomet. Chem. 2015, 775, $202-208$.

[28] E. Jürgens, B. Wucher, F. Rominger, K. W. Törnroos, D. Kunz, Chem. Commun. 2015, 51, 1897-1900.

[29] J. T. Lee, P. J. Thomas, H. Alper, J. Org. Chem. 2001, 66, 5424-5426.

[30] T. L. Church, Y. D. Y. L. Getzler, C. M. Byrne, G. W. Coates, Chem. Commun. 2007, 657-674.

[31] Y. Tian, E. Jürgens, D. Kunz, Chem. Commun. 2018, 54, 11340-11343.

[32] Y. Tian, E. Jürgens, K. Mill, R. Jordan, T. Maulbetsch, D. Kunz, ChemCatChem 2019, 11, 4028-4035. 
[33] D. Milstein, J. C. Calabrese, J. Am. Chem. Soc. 1982, 104, 3773-3774.

[34] P. M. Maitlis, A. Haynes, G. J. Sunley, M. J. Howard, J. Chem. Soc. - Dalton Trans. 1996, 2187-2196.

[35] M. J. Calhorda, A. M. Galvao, C. Unaleroglu, A. A. Zlota, F. Frolow, D. Milstein, Organometallics 1993, 12, 3316-3325.

[36] A. A. Zlota, F. Frolow, D. Milstein, Organometallics 1990, 9, 1300-1302.

[37] D. Forster, J. Chem. Soc. Dalton Trans. 1979, 1639.

[38] A. Haynes, P. M. Maitlis, G. E. Morris, G. J. Sunley, H. Adams, P. W. Badger, C. M. Bowers, D. B. Cook, P. I. P. Elliott, T. Ghaffar, et al., J. Am. Chem. Soc. 2004, 126, 2847-2861.

[39] G. M. Sheldrick, SADABS 2012/1; University of Göttingen, Göttingen, Germany, 2012.

[40] a) G. M. Sheldrick, Acta Cryst. 2008, A64, 112-122; b) G. M. Sheldrick, Acta Cryst. 2015, C71, 3-8; c) C. B. Hübschle, G. M. Sheldrick, B. Dittrich, J. Appl. Cryst. 2011, 44, 1281-1284. 